\title{
Effect of Artemether Treatment on Plasma Lipid Profile in Malaria
}

\author{
Nkereuwem Edikpo*, Paul Obiekwe Okonkwo, Elias Adikwu \\ Department of Pharmacology, Faculty of Basic Medical Sciences, University of Port Harcourt, Choba, Nigeria \\ Email: uwemnkere@gmail.com
}

Received 13 April 2014; revised 25 May 2014; accepted 7 June 2014

Copyright (C) 2014 by authors and Scientific Research Publishing Inc.

This work is licensed under the Creative Commons Attribution International License (CC BY).

http://creativecommons.org/licenses/by/4.0/

(c) () Open Access

\begin{abstract}
This study was undertaken to assess the effect of artemether treatment on plasma lipid profile in malaria infection. While the importance of lipid to plasmodial infective processes and metabolism is being increasingly appreciated, little is known about the attendant effect of chemotherapy on plasma lipid profile. Thirty patients with uncomplicated malaria were chosen from two secondary health-care facilities in Yobe State, Nigeria with informed consents and ethical clearance. Based on predetermined inclusion criteria patients were given $3.2 \mathrm{mg} / \mathrm{kg}$ of artemether with $1.6 \mathrm{mg} / \mathrm{kg}$ on subsequent days for a total of five days. This was done after the collection of urine and blood samples for urinalysis, malaria parasite density count and serum lipid analysis. A follow-up was planned seven (7) days from first dose during when clinical assessment and repeat malaria parasite density count and serum lipid analysis were done. Data were analyzed with statistical package for social scientist and Microsoft Excel spread sheet while level of significance at $p \leq$ 0.05 was calculated using paired t-test. Serum HDL cholesterol concentration recorded a significant decline of $0.13 \mathrm{mmol} / \mathrm{L}$ from a pre-treatment mean concentration of $1.17 \mathrm{mmol} / \mathrm{L}(\mathrm{p}<0.04)$. Triglyceride, total cholesterol, LDL-cholesterol, VLDL-cholesterol showed increment or reductions that were not significant. The clinical cure rate was $50 \%$ and mean percentage reduction in parasitaemia was $52 \%$. A possible explanation for this low cure rate could be resistance, unfavorable pharmacokinetic disposition or lack of full adherence. A trial with complete parasite clearance, possibly using artemisinin-based combinational therapy would provide a more compelling result.
\end{abstract}

\section{Keywords}

Artemether, Plasma Lipid Profile, Malaria, Humans

\footnotetext{
${ }^{*}$ Corresponding author.
} 


\section{Introduction}

Malaria is an acute febrile illness caused by haemoprotozoal organisms of the phylum Apicomplexa and genus Plasmodium. Its history is a fascinating story of mankind's struggle with a debilitating and devastating illness that at one time afflicted more than two thirds of the world's population and helped to shape the course of history [1]. Though as early as the Hippocratic era malaria was clearly identified with marshes, it was not until the late nineteenth century that Ross identified mosquito as the vector [2] and Charles Louis Alphonse Laveran showed plasmodium to be the pathogen [3]. Although numerous plasmodial species have been identified that naturally infect a variety of animals, only four are pathogenic to man. These are Plasmodium falciparum (P. falciparum) - the most pathogenic and the cause of most complications of malaria, Plasmodium vivax (P. vivax), Plasmodium ovale (P. ovale) and Plasmodium malariae (P. malariae). However, P. knowlesi which is evolutionary related to human forms has been implicated in naturally acquired symptomatic malaria in a 39-year-old Thai man [4].

It is a well established fact that the parasite induces in the host certain metabolic and biochemical changes observable both in the erythrocyte [5] [6] and in the serum [7]-[9]. These changes are not unrelated to the fact that, glycosylphosphatidyl inositol, the major component of malaria toxin is known to induce the production of inflammatory cytokines via interaction with CD14 on cells of the innate immune system with concomitant activation of toll-like receptors [10]. Part of these changes involves disorders in lipid transport and metabolism. Protein and lipid trafficking events are said to underlie host cell invagination during parasite entry that results in the parasitophorous vacuole, maintenance of the vacuole, development of antigenic and structural alterations in the cytoplasm and membrane of erythrocyte, new pathways of nutrient import and the machinery to sustain parasite protein export to the vacuolar and erythrocytic domains [11].

The parasite is critically dependent on macromolecules derived from host plasma and erythrocyte membrane. Grellier et al. [12] demonstrated that parasite growth was complete using serum-free medium supplemented only with a human high density lipoprotein (HDL) fraction. Development was incomplete with the low density lipoprotein fraction (LDL) and did not occur at all with the very low density lipoprotein (VLDL) fraction. Specific fatty acid combinations presumably derived from the HDL fraction and free fatty acids were said to provide optimum growth environment [13]. Of particular importance is erythrocyte membrane cholesterol and sphingolipid to parasite entry and continued existence in the intravacuolar environment. Lipid raft cholesterol is said to be absolutely needed for raft protein association and depletion of membrane cholesterol by methyl $\beta$-cyclodextrin (MBCD) is said to lead to abrogation of infection and expulsion of the parasite from the erythrocyte [14]. Inhibition of parasite sphingomyelin synthase by dl-threo-1-phenyl-2-palmitoylamino-3-morpholino-1-propanol (PPMP) leads to arrest of tubovesicular network formation, a transport organelle extending from the parasitophorous vacuole membrane to the periphery of the erythrocyte and is used for nutrient import [15]. Because of these profound effect of malaria infection on blood lipids and unique pathways of lipid metabolism in plasmodium [16], targeting of lipid metabolism has been considered attractive for rational antimalarial chemotherapeutic drug design and development. In furtherance of the research on lipid and malaria, artemether was chosen. It is now used as one of the artemisinin backbones in combinational therapy (ACT) of malaria in areas of the world where multidrug resistant Plasmodium falciparum malaria is prevalent [17] [18]. As a rapidly acting blood schizontocide, earlier studies with artemether monotherapy revealed fever clearance time and parasitological cure rate of 30 hours and $>90 \%$ respectively [45] [46]. Due to its lipid solubility we therefore set out to examine the concomitant changes in plasma lipid profile in malaria in response to artemether chemotherapy.

\section{Materials and Methods}

\subsection{Study Design}

The study was a single-blind, self-controlled experimental model.

\subsection{Subjects}

Thirty patients with clinically mild and moderate malaria were chosen by stratified sampling method. They were chosen predominantly from General Hospitals, Potiskum and Buni-Yadi, both located in Yobe State, in the sudan savannah belt of Nigeria where annual temperature and rainfall average $37^{\circ} \mathrm{C}$ and $16.7 \mathrm{~cm}$ respectively: as a result of this, malaria transmission can be described as relatively stable. Potiskum and Buni-Yadi are 100 kilo- 
meters east and 55 kilometers south respectively of Damaturu (Location: $11.75^{\circ} \mathrm{N}, 11.96^{\circ} \mathrm{E}$ ), the state capital and, majority of the population are subsistent farmers and herdsmen. Informed consents and ethical clearance were obtained from the patients (or their guardians) and the Principal Medical officer in-charge of the hospitals respectively.

\subsection{Selection of Subjects}

Patients were selected based on certain inclusion and exclusion criteria. Sample size, $\mathrm{n}=30$ was calculated from the formula:

$$
\frac{(\mathrm{u}+\mathrm{v})^{2}\left(\delta_{1}^{2}+\delta_{2}^{2}\right)}{\left(\mu_{1}-\mu_{2}\right)^{2}}
$$

where:

$\mathrm{u}=$ one-sided percentage point of the normal distribution corresponding to $100 \%$-the power (power of the study was fixed at $90 \%$, so $\mathrm{u}=1.28$ );

$\mathrm{v}=$ Percentage point of the normal distribution corresponding to the (two-sided) significance level (this was 1.96 for 5 percentage point);

$\left(\delta_{1}, \delta_{2}\right)=$ Standard deviations of pre-treatment and post-treatment groups respectively $(0.4,0.4)$; and

$\left(\mu_{1}-\mu_{2}\right)=$ The required difference between the mean of pre-treatment and post-treatment groups $(0.25)$.

This resulted in a sample size of 32.8 for each group and, was approximated to 30. Patients were co-opted into the study according to predetermined inclusion and exclusion criteria.

\subsection{Treatment and Intervention}

A patient who was deemed fit and was co-opted into the study was placed in a recumbent position and reassured. A full explanation of what the study entailed was made to the patient or parents and consent obtained. Five (5) millilitres of blood were drawn from the antecubital vein using universal safety precautions: 3 millilitres were immediately transferred into a plain sterile bottle, centrifuged and the serum stored and transported on ice parks for serum lipid assay within 48 hours. A drop of blood was immediately transferred unto a clean glass slide for thick smear for malaria parasite density estimation. The remaining volume of blood was transferred into a heparinised bottle for haemoglobin concentration estimation. On-the-spot urine sample was also collected from the patient to test for glycosuria and proteinuria and for pregnancy (in women of child-bearing age); all specimen containers were code-labelled.

Patients co-opted into the study were then given $3.2 \mathrm{mg}$ per kilogram body-weight of artemether, administered in the hospital orally or intramuscularly. $1.6 \mathrm{mg}$ per kilogram body-weight was repeated on subsequent days for the remaining four days (in the hospital for those allotted to receive artemether intramuscularly). For those receiving oral drugs, the remaining doses were completed at home. No analgesic or haematinic was administered. ARTEM branch of artemether, purchased from the Sales Representative of Nigeria-German Chemicals at Jos, North-Central Nigeria was used.

Subjects were reassessed one week later by clinical and laboratory methods. Resolution or persistence of initial clinical features of malaria earlier recorded was noted. Also noted were signs and symptoms that could have been attributed to artemether toxicity. A numerical score was accorded patient according to clinical response as follows.

\begin{tabular}{lc}
\hline Clinical Response & Score \\
\hline Complete resolution of symptoms & 2 \\
Resolution of symptoms within 48 hr but with resurgence as at follow-up & 1 \\
No clinical response at inception of treatment & 0 \\
\hline
\end{tabular}

Percentage changes in malaria parasite density were calculated as follows:

$\underline{\text { Pre-treatment MP density }- \text { Post-treatment MP density } \times 100}$

Pre-treatment MP density 1 
Accordingly, a positive sign to a change denotes decrease in MP density after treatment while a negative sign denotes an increase.

Statistical analysis was done with Microsoft Excel spreadsheet (2003 version) and Statistical Package for Social Sciences (SPSS) version 10.0. Paired t-test was used for significance testing, considering 0.05 to be significant.

\subsection{Estimation of Serum Lipid Profile}

Serum lipid profile: triglyceride, total cholesterol, high-density lipoprotein cholesterol, very low-density lipoprotein cholesterol, low-density lipoprotein cholesterol were assayed by a combination of enzymatic and spectrophotometric methods. Methods and calculations used for estimation of serum triglyceride and cholesterol are as outlined in Triglyceride-GPO Reagent Set by TECO Diagnostics, USA (2003).

Very Low-Density Lipoprotein Cholesterol was estimated using the formula below.

Friedewald Formula [20] was used in calculating this. It is given by:

$$
\text { VLDL }- \text { cholesterol }(\mathrm{mmol} / \mathrm{L})=\frac{\text { triglyceride }(\mathrm{mmol} / \mathrm{L})}{2.2}
$$

Low-Density Lipoprotein Cholesterol was estimated using Friedewald Formula [20] as shown below.

$$
\text { LDL }- \text { cholesterol }=\text { Total cholesterol }-(\text { HDL }- \text { cholesterol }+ \text { VLDL }- \text { cholesterol })
$$

\subsection{Estimation of Malaria Parasite Density}

A drop of blood from a plastic pipette was transferred from a freshly drawn blood to the centre of a clean glass slide. The tip of the pipette was used in dispersing the blood in a circular fashion, applying care not to cause rouleaux formation. This was left to dry in the air. The freshly prepared Giemsa stain was poured gently on the film and left to stain for 30 minutes in a horizontal position after which excess stain was washed off with clean water and left to dry again before reading. With a drop of cedar oil, 40× magnification lens was used to ascertain areas of the film with the most evenly distributed white blood cells (WBC). With 100× magnification lens, 200 WBC were counted together with the associated malaria parasites. The density of malaria parasite was calculated using an estimated WBC count of $8000 / \mathrm{ml}$ as follows.

$$
\frac{\text { Malaria Parasite Density }}{(\text { per } \mu \text { L of blood })}=\frac{8000 \times \text { parasites counted against } 200 \text { WBC }}{200}
$$

The method and calculation used in this section is as recommended [21].

\subsection{Screening Test}

Measurement of urinary glucose and urinary protein were screening tests used for patients' eligibility before being co-opted into the research program [22] [23].

\section{Results}

The total number of patients used for the study was $30(n=30)$, with 13 males and 17 females and, mean and median ages of patients were 27 and 25 years respectively with a standard deviation of 12 years. The age range was 54 years. Table 1 captures patients' biodata, clinical responses, and absolute and percentage changes in malaria parasite density and serum lipid estimations.

- Percentage changes in serum lipid profile were calculated as follows:

$$
\frac{\text { Pr-treatment value }(\mathrm{mmol} / \mathrm{L})-\text { Post-treatment value }(\mathrm{mmol} / \mathrm{L}) \times 100}{\text { Pre-treatment value }(\mathrm{mmol} / \mathrm{L}) 1}
$$

Therefore, positive sign to a percentage change denotes decrease of post-treatment value from pre-treatment value and a negative sign denotes an increase from the pre-treatment value.

- Percentage changes in malaria parasite density were calculated as follows. 
Table 1. Biodata, clinical response, changes in MP density and serum lipid profile.

\begin{tabular}{|c|c|c|c|c|c|c|c|c|c|c|c|c|c|c|c|}
\hline \multirow{3}{*}{$\frac{\dot{\Xi}}{\dot{\Xi}}$} & \multirow{3}{*}{ 菌 } & \multirow{3}{*}{ ஸे } & \multirow{3}{*}{ 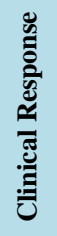 } & \multirow{3}{*}{ 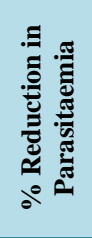 } & \multirow{3}{*}{ 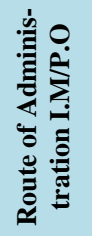 } & \multicolumn{10}{|c|}{ Serum Lipid Profile Change } \\
\hline & & & & & & \multicolumn{2}{|c|}{ TG } & \multicolumn{2}{|c|}{ T.Chol } & \multicolumn{2}{|c|}{ HDL-C } & \multicolumn{2}{|c|}{ LDL-C } & \multicolumn{2}{|c|}{ VLDL-C } \\
\hline & & & & & & $\begin{array}{c}\text { Abs } \\
\text { Change } \\
(\mathrm{mmol} / \mathrm{L})\end{array}$ & $\begin{array}{c}\text { \% } \\
\text { Change }\end{array}$ & $\begin{array}{c}\text { Abs } \\
\text { Change } \\
(\mathrm{mmol} / \mathrm{L})\end{array}$ & $\begin{array}{c}\% \\
\text { Change }\end{array}$ & $\begin{array}{c}\text { Abs } \\
\text { Change } \\
(\mathrm{mmol} / \mathrm{L})\end{array}$ & $\begin{array}{c}\% \\
\text { Change }\end{array}$ & $\begin{array}{c}\text { Abs } \\
\text { Change } \\
(\mathrm{mmol} / \mathrm{L})\end{array}$ & $\begin{array}{c}\text { \% } \\
\text { Change }\end{array}$ & $\begin{array}{c}\text { Abs } \\
\text { Change } \\
(\mathrm{mmol} / \mathrm{L})\end{array}$ & \% \\
\hline 1 & 39 & $\mathrm{~F}$ & $2+$ & $86 \%$ & $\mathrm{IM}$ & +0.1 & $8 \%$ & +0.3 & $9 \%$ & -0.1 & $11 \%$ & +1.8 & $95 \%$ & -0.1 & $17 \%$ \\
\hline 2 & 3 & M & $1+$ & $50 \%$ & $\mathrm{PO}$ & +0.5 & $45 \%$ & +1.6 & $59 \%$ & 0 & $0 \%$ & +1.4 & $93 \%$ & +0.2 & $40 \%$ \\
\hline 3 & 38 & M & $2+$ & $60 \%$ & IM & +0.7 & $54 \%$ & -0 & $0 \%$ & -0.3 & $25 \%$ & 0 & $0 \%$ & +0.3 & $50 \%$ \\
\hline 4 & 25 & M & 0 & $9 \%$ & $\mathrm{IM}$ & +0.3 & $30 \%$ & +0.2 & $4 \%$ & -0.5 & $38 \%$ & +0.6 & $19 \%$ & +0.1 & $20 \%$ \\
\hline 5 & 44 & $\mathrm{~F}$ & $1+$ & $58 \%$ & $\mathrm{IM}$ & -0.1 & $8 \%$ & +0.3 & $6 \%$ & -0.3 & $27 \%$ & +0.7 & $23 \%$ & -0.1 & $17 \%$ \\
\hline 6 & 3 & M & $1+$ & $52 \%$ & PO & +0.3 & $23 \%$ & +0.1 & $3 \%$ & -0.3 & $30 \%$ & +0.3 & $17 \%$ & +0.1 & $17 \%$ \\
\hline 7 & 44 & M & $1+$ & $60 \%$ & $\mathrm{IM}$ & +0.5 & $36 \%$ & +0.8 & $15 \%$ & 0 & $0 \%$ & +0.5 & $14 \%$ & +0.3 & $50 \%$ \\
\hline 8 & 38 & M & $2+$ & $82 \%$ & $\mathrm{IM}$ & +0.4 & $40 \%$ & -0.5 & $11 \%$ & +0.1 & $10 \%$ & -0.7 & $22 \%$ & +0.1 & $20 \%$ \\
\hline 9 & 14 & $\mathrm{~F}$ & $1+$ & $57 \%$ & $\mathrm{PO}$ & +0.1 & $9 \%$ & -0.6 & $16 \%$ & +0.1 & $14 \%$ & -0.7 & $28 \%$ & 0 & $0 \%$ \\
\hline 10 & 22 & $\mathrm{~F}$ & $2+$ & $86 \%$ & $\mathrm{IM}$ & +0.5 & $28 \%$ & -0.9 & $15 \%$ & -0.2 & $14 \%$ & -0.9 & $24 \%$ & +0.2 & $25 \%$ \\
\hline 11 & 15 & $\mathrm{~F}$ & $1+$ & $50 \%$ & $\mathrm{IM}$ & -0.4 & $24 \%$ & -0.2 & $5 \%$ & +0.2 & $20 \%$ & -0.2 & $8 \%$ & -0.2 & $25 \%$ \\
\hline 12 & 22 & $\mathrm{~F}$ & $2+$ & $60 \%$ & $\mathrm{IM}$ & +0.1 & $6 \%$ & -0.3 & $5 \%$ & +0.1 & $8 \%$ & -0.5 & $14 \%$ & +0.1 & $13 \%$ \\
\hline 13 & 30 & $\mathrm{~F}$ & 0 & $20 \%$ & $\mathrm{PO}$ & +0.8 & $89 \%$ & -0.4 & $8 \%$ & +0.1 & $8 \%$ & -0.9 & $25 \%$ & +0.4 & $100 \%$ \\
\hline 14 & 38 & $\mathrm{M}$ & $1+$ & $50 \%$ & $\mathrm{IM}$ & -0.3 & $17 \%$ & +0.2 & $5 \%$ & +0.2 & $17 \%$ & +0.1 & $5 \%$ & -0.1 & $13 \%$ \\
\hline 15 & 40 & $\mathrm{~F}$ & 0 & $33 \%$ & $\mathrm{IM}$ & +0.3 & $21 \%$ & -0.3 & $6 \%$ & +0.3 & $30 \%$ & -0.8 & $26 \%$ & +0.2 & $33 \%$ \\
\hline 16 & 25 & $\mathrm{~F}$ & $2+$ & $82 \%$ & $\mathrm{IM}$ & -0.3 & $20 \%$ & +0.8 & $19 \%$ & -0.1 & $10 \%$ & +1.1 & $44 \%$ & -0.2 & $29 \%$ \\
\hline 17 & 25 & $\mathrm{~F}$ & $2+$ & $60 \%$ & PO & -1.4 & $58 \%$ & -1.3 & $26 \%$ & -0.2 & $17 \%$ & -0.5 & $19 \%$ & -0.6 & $55 \%$ \\
\hline 18 & 30 & $\mathrm{~F}$ & $2+$ & $84 \%$ & $\mathrm{PO}$ & +0.1 & $6 \%$ & +2.1 & $42 \%$ & -0.2 & $10 \%$ & +2.2 & $100 \%$ & +0.1 & $13 \%$ \\
\hline 19 & 57 & $\mathrm{M}$ & $2+$ & $60 \%$ & $\mathrm{IM}$ & -1.3 & $57 \%$ & -1.4 & $22 \%$ & -0.5 & $33 \%$ & -0.4 & $10 \%$ & -0.5 & $50 \%$ \\
\hline 20 & 26 & $\mathrm{~F}$ & 0 & $-24 \%$ & $\mathrm{PO}$ & -0.7 & $41 \%$ & -0.6 & $12 \%$ & -1.3 & $59 \%$ & +1 & $50 \%$ & -0.3 & $38 \%$ \\
\hline 21 & 19 & $\mathrm{~F}$ & $1+$ & $45 \%$ & $\mathrm{PO}$ & +1 & $111 \%$ & -0.4 & $8 \%$ & +0.1 & $8 \%$ & -1 & $28 \%$ & +0.5 & $125 \%$ \\
\hline 22 & 20 & $\mathrm{M}$ & 0 & $-11 \%$ & $\mathrm{IM}$ & +0.4 & $25 \%$ & +0.9 & $24 \%$ & -0.4 & $33 \%$ & +1.1 & $61 \%$ & +0.2 & $29 \%$ \\
\hline 23 & 4 & $\mathrm{M}$ & $1+$ & $-50 \%$ & $\mathrm{IM}$ & +0.5 & $56 \%$ & +1.3 & $35 \%$ & +0.2 & $20 \%$ & +0.9 & $39 \%$ & +0.2 & $50 \%$ \\
\hline 24 & 22 & $\mathrm{~F}$ & $2+$ & $86 \%$ & $\mathrm{PO}$ & -0.2 & $15 \%$ & +0.2 & $5 \%$ & 0 & $0 \%$ & +0.3 & $12 \%$ & -0.1 & $17 \%$ \\
\hline 25 & 30 & $\mathrm{~F}$ & $1+$ & $57 \%$ & $\mathrm{IM}$ & +0.3 & $38 \%$ & -0.4 & $8 \%$ & 0 & $0 \%$ & -0.5 & $14 \%$ & +0.1 & $25 \%$ \\
\hline 26 & 27 & $\mathrm{M}$ & $2+$ & $60 \%$ & PO & -0.2 & $13 \%$ & -0.8 & $15 \%$ & -0.1 & $10 \%$ & -0.6 & $16 \%$ & -0.1 & $14 \%$ \\
\hline 27 & 35 & $\mathrm{~F}$ & $2+$ & $78 \%$ & $\mathrm{IM}$ & +0.1 & $10 \%$ & +0.5 & $14 \%$ & -0.1 & $10 \%$ & +0.6 & $27 \%$ & 0 & $0 \%$ \\
\hline 28 & 22 & $\mathrm{M}$ & $2+$ & $80 \%$ & $\mathrm{IM}$ & +0.2 & $18 \%$ & -0.4 & $9 \%$ & -0.1 & $9 \%$ & -0.4 & $14 \%$ & +0.1 & $20 \%$ \\
\hline 29 & 22 & $\mathrm{~F}$ & $2+$ & $82 \%$ & $\mathrm{PO}$ & +0.2 & $15 \%$ & -0.5 & $10 \%$ & +0.1 & $9 \%$ & -0.7 & $23 \%$ & +0.1 & $17 \%$ \\
\hline 30 & 30 & $\mathrm{M}$ & $2+$ & $60 \%$ & PO & -1.5 & $52 \%$ & -0.5 & $10 \%$ & -0.6 & $38 \%$ & +0.8 & $42 \%$ & -0.7 & $54 \%$ \\
\hline
\end{tabular}


Pre-treatment MP density - Post-treatment MP density $\times 100$

Pre-treatment MP density 1

Accordingly, a positive sign to a change denotes decrease in MP density after treatment while a negative sign denotes an increase.

The mean pre-treatment concentration for serum triglyceride was $1.44 \pm 0.48 \mathrm{mmol} / \mathrm{L}$ and that for posttreatment concentrations was $1.47 \pm 0.35 \mathrm{mmol} / \mathrm{L}$. The standard errors were $0.09 \mathrm{mmol} / \mathrm{L}$ and $0.06 \mathrm{mmol} / \mathrm{L}$ for pre-treatment and post-treatment concentrations respectively. Comparison of pre-treatment and post-treatment mean concentrations showed yielded a t-value of 0.3 with a df of 29 and P-value of 0.77 . This was not considered significant. These data are presented in Table 2 below.

Values for serum total cholesterol were as follows: mean of $64 \pm 0.86 \mathrm{mmol} / \mathrm{L}$ and $4.63 \pm 0.81 \mathrm{mmol} / \mathrm{L}$ for pre-treatment and post-treatment concentration respectively. Comparison of these two means showed a t-value of 0.05, with 29 degrees of freedom, and a p-value of 0.96; this was not considered significant. Serum HDL-cholesterol concentrations estimation showed a pre-treatment mean value of $1.17 \pm 0.32 \mathrm{mmol} / \mathrm{L}$ and a post-treatment mean value of $1.04 \pm 0.24 \mathrm{mmol} / \mathrm{L}$. Standard errors of $0.06 \mathrm{mmol} / \mathrm{L}$ and $0.04 \mathrm{mmol} / \mathrm{L}$ for pretreatment and post-treatment concentrations respectively were calculated. Comparison of the two mean showed $\mathrm{t}$ $=2.18, \mathrm{df}=29, \mathrm{p}=0.04$. This was considered significant. The mean value for pre-treatment concentrations of serum LDL-cholesterol was $2.82 \pm 0.76 \mathrm{mmol} / \mathrm{L}$ and that for post-treatment concentrations was $2.97 \pm 0.68$ $\mathrm{mmol} / \mathrm{L}$. The standard errors were $0.14 \mathrm{mmol} / \mathrm{L}$ and $0.12 \mathrm{mmol} / \mathrm{L}$ for pre-treatment and post-treatment concentrations respectively. Comparison of pre-treatment and post-treatment means showed $t=0.96, \mathrm{df}=29$ degrees, $\mathrm{p}$ $=0.34$. This was not significant. Serum VLDL-Cholesterol concentrations had a pre-treatment and a posttreatment mean value of $0.66 \pm 0.21 \mathrm{mmol} / \mathrm{L}$ and $0.67 \pm 0.16$ respectively. Standard errors of $0.04 \mathrm{mmol} / \mathrm{L}$ and $0.03 \mathrm{mmol} / \mathrm{L}$ for pre-treatment and post-treatment concentrations respectively were calculated. Comparison of the two mean showed $t=0.2, \mathrm{df}=29, \mathrm{p}=0.84$. This was not significant. These are presented in Table 2 above.

Table 3 below shows the mean pre-treatment malaria parasite density for all patients $(4352 / \mu \mathrm{L})$, the mean post-treatment malaria parasite density $(1927 / \mu \mathrm{L})$ and the mean percentage reduction in malaria parasite density (52\%). None of the 30 patients had complete parasite clearance. In fact, 3 actually recorded an increase in parasitaemia, 2 of which belonged to the group that received intra-muscular artemether. For those patients who received oral artemether (12; 40\%), the mean percentage reduction in parasitaemia was $53 \%$ as against $47 \%$ for those who received intra-muscular artemether (18; 60\%).

The clinical cure rate was fifty percent (50\%) while the number of patients that had initial clinical response but with recurrence of symptoms at follow-up was ten (33\%). Five patients (17\%) showed no response at all after treatment with artemether. The mean haemoglobin concentration prior to treatment with artemether was 11.5 $\mathrm{g} / \mathrm{dL}$ as compared to $11.4 \mathrm{~g} / \mathrm{dL}$ after treatment with artemether. The difference was not significant.

Table 2. Concentration of serum lipid fractions.

\begin{tabular}{cccc}
\hline $\begin{array}{c}\text { Substance estimated in } \\
\text { Serum (mmol/L) }\end{array}$ & $\begin{array}{c}\text { Pre-treatment concentration } \\
\text { Mean } \pm \text { SD (mmol/L) }\end{array}$ & $\begin{array}{c}\text { Post-treatment concentration } \\
\text { Mean } \pm \text { SD (mmol/L) }\end{array}$ & p-Value \\
\hline Triglyceride & $1.44 \pm 0.48$ & $1.47 \pm 0.35$ & 0.77 \\
Total cholesterol & $4.64 \pm 0.86$ & $4.63 \pm 0.81$ & 0.96 \\
HDL-cholesterol & $1.17 \pm 0.32$ & $1.04 \pm 0.24$ & 0.04 \\
LDL-cholesterol & $2.82 \pm 0.76$ & $2.97 \pm 0.68$ & 0.34 \\
VLDL-cholesterol & $0.66 \pm 0.21$ & $0.67 \pm 0.16$ & 0.84 \\
\hline
\end{tabular}

A p-value of $\leq 0.05$ was considered significant.

Table 3. Malaria parasite density (per $\mu \mathrm{L}$ ).

\begin{tabular}{cccc} 
& Pre-treatment & Post-treatment & Mean \% reduction in parasitaemia \\
\hline MP density & 4352 & 1927 & $52 \%$ \\
\hline
\end{tabular}




\section{Discussion}

Malaria is an acute febrile illness caused by hemoprotozoal organisms of the genus Plasmodium. It affects predominantly the tropical and semi-tropical regions of the world and is transmitted through the bite of female anopheline mosquito in which the sexual half of its dual life-cycle occurs and has further contributed to the economic predicament of this region [24]. The severity of the 'malaria burden' became all the more pronounced as the parasite developed resistance to almost all available antimalarials-chloroquine, sulfadoxine-pyrimethamine and mefloquine from the 1960s to 80s [25]-[29]. This created room for more research which led to the isolation and purification of artemesinin with clinical efficacy [30]-[32]. But this experimental breakthrough was characterised by a particular limitation - the poor solubility of artemisinin in water and oil which led to the birth of other artemisinin derivatives [33]-[37]. Artemether is one of the oil soluble artemisinin derivatives that is clinically used for the treatment of malaria. Its clinical efficacy has been proven in various clinical studies [38] [39]. Despite it reported efficacy clinical reports demonstrated that treatment of mild to moderate cases of malaria with artemether carries with it an alteration in plasma lipid profile. However, out of the five commonly measured plasma lipid parameters, it was only the change in the serum high density lipoprotein-cholesterol (HDL-C) that was significant. Comparison of pre-treatment mean concentration $(1.17 \pm 0.32 \mathrm{mmol} / \mathrm{L})$ and post-treatment mean concentration $(1.04 \pm 0.24 \mathrm{mmol} / \mathrm{L})$ revealed a decrease of $0.13 \mathrm{mmol} / \mathrm{L}$ that was significant at a p-value of 0.04 with 29 degree of freedom. The other serum lipid fractions-triglyceride, total cholesterol, low-density lipoprotein cholesterol and very low-density lipoprotein cholesterol also showed changes after treatment. However, the changes recorded in these fractions were not significant: an increase of 0.03/L was recorded for serum triglyceride from a pre-treatment mean concentration of $0.44 \mathrm{mmol} / \mathrm{L}$; this was not significant at a p-value of 0.77 with 29 degree of freedom. Serum low-density lipoprotein cholesterol and very low-density lipoprotein cholesterol mean concentrations also were on the increase after treatment. LDL-C increased by about 0.15 $\mathrm{mmol} / \mathrm{L}$ and VLDL-C by about $0.01 \mathrm{mmol} / \mathrm{L}$; these were not significant at p-values of 0.34 and 0.84 respectively, and 29 degree of freedom. A reduction of $0.01 \mathrm{mmol} / \mathrm{L}$ was recorded in the serum total cholesterol concentration and was also not significant.

Research into plasma lipid profile with respect to malaria parasitaemia and after treatment is a relatively new field and as such, there is paucity of findings for comparison. However, accessible research literature with regards to lipid and malaria attest to the fact that malaria parasitaemia induces in the serum varied and profound changes most especially in triglyceride and cholesterol portions. Chrisna et al. [40] reported increases in serum triglyceride, total cholesterol and LDL-cholesterol concentrations in malaria patients though distinction was not made with regards to the severity of malaria. Serum HDL-cholesterol concentration was notably reduced in the same study. Nwobodo et al. [41] obtained the same pattern of plasma lipid changes in malaria. In a similar design to study the effect of malaria on common plasma lipid parameters, a previous study demonstrated a reverse of the immediately preceding studies. Triglycerides concentration was significantly lower in malaria patients than in uninfected controls while total cholesterol, LDL-cholesterol and HDL-cholesterol concentrations were significantly higher among malaria patients than in controls and these differences were said to be correlated with the severity of malaria. In a malaria treatment and prophylaxis study (with similar design as this work) where sustained parasite clearance was obtained [42], the mean serum concentrations of triglycerides and LDL-cholesterol were significantly reduced from the baseline pre-treatment values after complete parasite clearance while the serum total cholesterol and HDL-cholesterol concentrations were significantly increased. These changes are completely opposite to the results obtained in this study. Though the authors of this work could not access other works of similar design to arbitrate between these divergent results, the inability to obtain complete parasite clearance and reliance on only uncomplicated malaria may lie at the heart of these differences. Within the context of this study, it could safely be said that, the treatment of mild to moderate (uncomplicated malaria) induces a reduction in serum HDL-cholesterol concentrations.

Artemether is an excellent antimalarial agent and belongs to a group reputed to be the most rapidly acting schizontocidal agents [43] reducing parasite burden by a factor of $10^{4}$ /cycle of schizogony [44]. Clinical cure rates of ninety percent (90\%) and above have been recorded in previous studies with artemethermonotherapy. In this study, we obtained a clinical cure of only $50 \%$ of patients and a mean parasite reduction of $52 \%$ of pretreatment values. This contrasts sharply with previous studies [45] [46]. A possible explanation may be the phenomenon of recrudescence which plagues the artemisinin group of antimalarial agents when used as monotherapy or, an incipient form of resistance [47]-[50]. Additionally, the absorption of intramuscular artemether is documented as erratic and incomplete [51] [52]. This may have contributed to poor plasma concentration of ar- 
temether and consequently, poor clinical and parasitological outcome of the study. Since most of the patients (60\%) received intramuscular injections of artemether it is reasonable to implicate low plasma concentration of artemether and its more active metabolite, dihydroartemisinin in this low therapeutic outcome. Another, reason is the possibility that, for those patients who took oral medication, the initial clinical response could have prompted a false sense of recovery thereby leading to cessation of drug administration. This second reason is made plausible by the fact that ten patients (33\%) had initial response but had recurrence of symptom at follow-up.

A very positive note in clinical outcome was the safety of artemether. Follow-up assessment revealed no symptom referable to any organ-system. Even in the group that showed no clinical response ab initio, there were no additional complaints that could be traced to artemether. This is in keeping with the well documented clinical safety profile of artemisinin compounds [53]-[56], toxicity in animals studies notwithstanding [57]-[59]. An additional high-point of this study was the rapidity with which symptoms resolved: among those patients that had clinical response, follow-up assessment revealed resolution of fever, headache and joint pain (the commonest presenting symptoms in this study) before 48 hours from the commencement of treatment. This is in consonance with the well documented rapidity of action of artemether- 44.5 and 40.9 hours for fever clearance and parasite clearance time respectively [60].

\section{Conclusion}

In drawing a conclusion, this study has demonstrated that treatment of mild and moderate cases of malaria with artemether causes a significant reduction in serum HDL-cholesterol concentration. Because of the lack of total parasite clearance, any statement on the fate of the other lipid fractions would be scientifically unsound. This should await further studies with an artermisinin-based combinational agent, which is documented to have superior clinical efficacy to artemisinin derivatives alone.

\section{Limitation}

The limitation inherent in this work is with regards to the time frame of clinical and parasitological assessment of patients. Because of lack of financial support the malaria parasite assessment could not be done at a more frequent interval.

\section{References}

[1] Bruce-Chwatt, L.J. (1988) History of Malaria from Prehistory to Eradication. In: Wernsdorfer, W.H. and McGregor, I., Eds., Malaria: Principles and Practice of Malariology, Churchill Livingstone, Edinburgh, 1-59.

[2] Ross, R. (1897) On Some Peculiar Pigmented Cells Found in Two Mosquitoes Fed on Malarial Blood. British Medical Journal, 2, 1786-1788.

[3] Cox, F.E.G. (2010) History of the Discovery of the Malaria Parasites and Their Vectors. Parasites and Vectors, 3, 5. http://dx.doi.org/10.1186/1756-3305-3-5

[4] Jongwutiwes, S., Putaporntip, C., Iwasaki, T., Sata, T. and Kanbara, H. (2004) Naturally Acquired Plasmodium Knowlesi Malaria in Human in Thailand. Emerging Infectious Disease, 10, 2211-2213. http://dx.doi.org/10.3201/eid1012.040293

[5] Sherman, I.W. (1979) Biochemistry of Plasmodium. Microbiological Review, 43, 453-459.

[6] Hsiao, L.L., Howard, R.J., Aikawa, M. and Taraschi, T.F. (1991) Modification of Host Cell Membrane Lipid Composition by the Intraerythrocytic Human Malaria Parasite Plasmodium falciparum. Biochemistry Journal, 274, 121-132.

[7] Onongbu, I.C. and Onyeneke, E.C. (1983) Plasma Lipid Changes in Human Malaria. Tropical Medicine and Parasitology, 34, 193-196.

[8] Nilsson-Ehle, I. and Nilsson-Ehle, P. (1990) Changes in Plasma Lipoproteins in Acute Malaria. Journal of Internal Medicine, 227, 151-155. http://dx.doi.org/10.1111/j.1365-2796.1990.tb00136.x

[9] Mohanty, S., Mishra, S.K., Das, B.S., Sathpathy, S.K., Mohanty, D. and Patnaik, J. (1992) Altered Plasma Lipid Pattern in falciparum Malaria. Annals of Tropical Medical Parasitology, 86, 601-606.

[10] Clark, I.A., Alleva, L.M., Mills, A.C. and Cowden, W.B. (2004) Pathogenesis of Malaria and Clinically Similar Conditions. Clinical Microbiology Reviews, 17, 509-539. http://dx.doi.org/10.1128/CMR.17.3.509-539.2004

[11] Haldar, K., Mohandas, N., Samuel, B.U., Harrison, T., Hiller, N.L. and Akompong, T. (2002) Protein and Lipid Traf- 
ficking Induced in Erythrocytes Infected by Malaria Parasites. Cellular Microbiology, 4, 383. http://dx.doi.org/10.1046/j.1462-5822.2002.00204.x

[12] Grellier, P., Rigomier, D., Clavey, V., Fruchart, J.C. and Schrevel, J. (1991) Lipid Trafficking between High-Density Lipoproteins and Plasmodium falciparum-Infected Red Blood Cells. Journal of Cell Biology, 112, 267-277. http://dx.doi.org/10.1083/jcb.112.2.267

[13] Mitamura, T., Hanada, K., Ko-mitamura, E.P., Nishijima, M. and Horii, T. (2000) Serum Factors Governing Intraerythrocytic Development and Cell Cycle Progression of Plasmodium falciparum. Parasitology International, 49, $219-229$. http://dx.doi.org/10.1016/S1383-5769(00)00048-9

[14] Samuel, B.U., Mohandas, N., Harrison, T., McManus, H., Rosse, W. and Reid, M. (2001) The Role of Cholesterol and Glycosylphatidylinositol-Anchored Proteins of Erythrocyte Raft in Regulating Raft Protein Content and Malarial Infection. Journal of Biological Chemistry, 276, 29319-29329. http://dx.doi.org/10.1074/jbc.M101268200

[15] Lauer, S., Van Wye, J., Harrison, T., McManus, H., Samuel, B.U. and Hiller, N.L. (2000) Vacuolar Uptake of Host Components and a Role for Cholesterol and Sphigomyelin in Malarial Infection. The EMBO Journal, 19, 3556-3564. http://dx.doi.org/10.1093/emboj/19.14.3556

[16] Mitamura, T. and Palacpac, N.M.Q. (2003) Lipid Metabolism in Plasmodium falciparum-Infected Erythrocytes: Possible New Targets for Malaria Chemotherapy. Microbes and Infection, 5, 545-552. http://dx.doi.org/10.1016/S1286-4579(03)00070-4

[17] Mamoun, C.B., Prigge, S.T. and Vial, H. (2010) Targeting the Lipid Metabolic Pathways for the Treatment of Malaria. Drug Development Research, 71, 44-45.

[18] Grellier, P., Depoix, D., Schrével, J. and Florent, I. (2008) Discovery of New Targets for Antimalarial Chemotherapy. Parasite, 15, 219-225. http://dx.doi.org/10.1051/parasite/2008153219

[19] Kirkwood, B. (1994) Essentials of Medical Statistics. 4th Edition, Blackwell Science, Cambridge.

[20] Johnson, R., McNutt, P., MacMahon, S. and Robson, R. (1997) Use of the Friedewald Formula to Estimate LDL-Cholesterol in Patients with Chronic Renal Failure on Dialysis. Clinical Chemistry, 43, 2183-2184.

[21] Cheesbrough, M. (2005) District Laboratory in Tropical Countries, Part 1. 2nd Edition, Cambridge University Press, Cambridge. http://dx.doi.org/10.1017/CBO9780511581304

[22] American Association for Clinical Chemistry. (2009) Urinalysis. http://labtestsonline.org/understanding/analytes/urinalysis/sample.html

[23] Cowling, T. and Lloyd, E. (2011) The Correct Way to Perform a Medical Urinalysis. http://www.brighthub.com/science/medical/articles/71520.aspx

[24] Breman, J.G., Alilioand, M.S. and Mills, A. (2004) Conqueringthe Intolerable Burden of Malaria: What's New, What’s Needed: A Summary. http://www.ncbi.nlm.nih.gov/ books/NBK3750/

[25] UNICEF (2013) Malaria. http://www.unicef.org/health /index_malaria.html

[26] Barnadas, C., Ratsimbasoa, A., Tichit, M., Bouchier, C., Jahevitra, M., Picot, S. and Ménard, D. (2008) Plasmodium vivax Resistance to Chloroquine in Madagascar: Clinical Efficacy and Polymorphisms in pvmdr1 and pvcrt-o genes. Antimicrobial Agents Chemotherapy, 52, 4233-4240. http://dx.doi.org/10.1128/AAC.00578-08

[27] Rieckmann, K.H., Davis, D.R. and Hutton, D.C. (1989) Plasmodium vivax Resistance Tochloroquine? The Lancet, 334, 1183-1184. http://dx.doi.org/10.1016/S0140-6736(89)91792-3

[28] Kurcer, M.A., Simsek, Z. and Kurcer, Z. (2006) The Decreasing Efficacy of Chloroquine in the Treatment of Plasmodium vivax Malaria, in Sanliurfa, South-Eastern Turkey. Annals of Tropical Medicine and Parasitology, 100, 109-113. http://dx.doi.org/10.1179/136485906X86284

[29] Guthmann, J.P., Pittet, A., Lesage, A., Imwong, M., Lindegardh, N., et al. (2008) Plasmodium vivax Resistance to Chloroquine in Dawei, Southern Myanmar. Tropical Medicine and International Health, 13, 91-98. http://dx.doi.org/10.1111/j.1365-3156.2007.01978.x

[30] Tu, Y. (2011) The Discovery of Artemisinin (Qinghaosu) and Gifts from Chinese Medicine. Nature Medicine, 17, 1217-1220.

[31] Maude, C.J., Woodrow, C.J. and White, L.J. (2010) Artemisinin Antimalarials: Preserving the "Magic Bullet”. Drug Development Research, 71, 12-19.

[32] Awofeso, N. (2011) Project 523: Transformation of Artemisinin from Traditional Chinese Medicine to Mainstream Anti-Malaria Chemotherapy. Spatula DD, 1, 113-118.

[33] Li, J. and Zhou, B. (2010) Biological Actions of Artemisinin: Insights from Medicinal Chemistry Studies. Molecules, 15, 1378-1397. http://dx.doi.org/10.3390/molecules15031378

[34] Batty, K.T., Thu, L.T.A., Davis, T.M.E., Llet, K.F., Mai, T.X., Hung, N.C., et al. (1998) A Pharmacokineticand Phar- 
macodynamic Study of Intravenous vs Oralartesunate in Uncomplicated Falciparum Malaria. British Journal of Clinical Pharmacology, 45, 123-129.

[35] De Vries, V.J. and Dien, T.K. (1996) Clinical Pharmacology and Therapeutic Potential of Artemisinin and Its Derivatives in the Treatment of Malaria. Drugs, 52, 818-836. http://dx.doi.org/10.2165/00003495-199652060-00004

[36] Xiaonan, Z. (2010) Protein Binding Determination of Dihydroartemisinin (DHA) in Human Plasma by HPL CusingPost-Columnon-Line Alkali Derivatization and UV Detection. http://publications.lib.chalmers.se/records/fulltext/126728

[37] Li, Q.G., Peggins, J.O., Fleckenstein, L.L., Masonic, K., Heiffer, M.H. and Brewer, T.G. (1998) The Pharmacokinetics and Bioavailability of Dihydroartemisinin, Arteether, Artemether, Artesunicacid and Artelinic Acid in Rats. Journal of Pharmacy and Pharmacolology, 50, 173-182

[38] Krishna, S., Uhlemann, A. and Haynes, R.K. (2004) Artemisinins: Mechanisms of Action and Potential for Resistance. Drug Resistance Updates, 7, 233-244. http://dx.doi.org/10.1016/i.drup.2004.07.001

[39] Woodrow, C.J., Haynes, R.K. and Krishna, S. (2005) Artemisinins. Postgraduate Medicine Journal, 81, 71-78. http://dx.doi.org/10.1136/pgmj.2004.028399

[40] Krishna, A.P., Chandrik, A., Kumar, S., Acharya, M. and Patil, S.L. (2009) Variation in Common Lipid Parameters in Malaria Infected Patients. Indian Journal of Physiology and Pharmacology, 53, 271-274.

[41] Nwobodo, N., Okonkwo, P.O., Nwobodo, E. and Igwe, S.A. (2008) Evaluation of Effects of Malaria Infection on Serum Lipid Profile of Patients Attending Two District Hospitals in Enugu, Nigeria. Oriental Journal of Chemistry, 24, 415-418.

[42] Faucher, J., Ngou-Milama, E., Missinou, M.A., Ngomo, R., Kombila, M. and Kremsner, P.G. (2002) The Impact of Malaria on Common Lipid Parameters. Parasitology Research, 88, 1040-1043. http://dx.doi.org/10.1007/s00436-002-0712-6

[43] Chimanuka, B., Francois, G., Timperman, G., Heyden, Y.V., Holenz, J. and Plaizier-Vercammen, J. (2001) A Comparison of the Stage-Specific Efficacy of Chloroquine, Artemether and Dioncophylline B against the Rodent Malaria Parasite Plasmodium chabaudi chabaudi in Vivo. Parasitology Research, 87, 795-803. http://dx.doi.org/10.1007/s004360000358

[44] Woodrow, C.J., Haynes, R.K. and Krishna, S. (2005) Artemisinins. Postgraduate Medical Journal, 81, 71-78. http://dx.doi.org/10.1136/pgmj.2004.028399

[45] Karbwang, J., Bangchang, K.N., Thanavibul, A., Bunnang, D., Chongsuphajaisiddhi, T. and Harinasuta, T. (1992) Comparison of Oral Artemether and Mefloquine in Acute Uncomplicated Falciparum Malaria. The Lancet, 340, 12451248. http://dx.doi.org/10.1016/0140-6736(92)92947-E

[46] Silamut, K., Newton, P.N., Teja-Isavadharm, P., Suputtamongkol, Y., Siriyanonda, D., Rasameesoraj, M., et al. (2003) Artemether Bioavailability after Oral or Intramuscular Administration in Uncomplicated Falciparum Malaria. Antimicrobial Agents and Chemotherapy, 47, 3795-3798. http://dx.doi.org/10.1128/AAC.47.12.3795-3798.2003

[47] Alin, M.H., Ashton, M., Kihamia, C.M., Mtey, G.J.B. and Björkman, A. (1996) Multiple Dose Pharmacokinetics of Oral Artemisinin and Comparison of Its Efficacy with That of Oral Artesunate in Falciparum Malaria Patients. Transaction of Royal Society of Tropical Medicine and Hygiene, 90, 61-65. http://dx.doi.org/10.1016/S0035-9203(96)90480-0

[48] Ittarat, W., Pickard, A.L., Rattanasinganchan, P., Wilairatana, P., Looareesuwan, S. and Emery, K. (2003) Recrudescence in Artesunate-Treated Patients with Falciparum Malaria Is Dependent on Parasite Burden Not on Parasite Factors. American Journal of Tropical Medicine and Hygiene, 68, 147-152.

[49] Codd, A., Teuscher, F., Kyle, D.E., Cheng, Q. and Gatton, M.L. (2011) Artemisinin-Induced Parasite Dormancy: A Plausible Mechanism for Treatment Failure. Malaria Journal, 10, 56. http://dx.doi.org/10.1186/1475-2875-10-56

[50] Miller, L.H., Ackerman, H.C., Su, X. and Wellems, T.E. (2013) Is Recrudescence after Artemisinin Treatment Linked to a Dormancy Phenomenon? Nature Medicine, 19, 156-167. http://dx.doi.org/10.1038/nm.3073

[51] Teja-Isavadharm, P., Nosten, F., Kyle, D.E., Luxemburger, C., TerKulie, F. and Peggins, J.O. (1996) Comparative Bioavailability of Oral, Rectal, and Intramuscular Artemether in Healthy Subjects: Use of Simultaneous Measurement by High Performance Liquid Chromatography and Bioassay. British Journal of Clinical Pharmacology, 42, 599-604. http://dx.doi.org/10.1111/j.1365-2125.1996.tb00115.x

[52] Karbwang, J., Na-Bancgchang, K., Congpuong, K. and Thanayibul, A. (1997) Pharmacokinetics and Bioavailability of Oral and Intramuscular Artemether. European Journal of Clinical Pharmacology, 52, 307-310. http://dx.doi.org/10.1007/s002280050295

[53] Gordi, T. and Lepist, E.I. (2004) Artemisinin Derivatives: Toxic for Laboratory Animals, Safe for Humans? Toxicological Letters, 147, 99-107. http://dx.doi.org/10.1016/j.toxlet.2003.12.009 
[54] Hien, T.T., Turner, G.D., Mai, N.T., Phu, N.H., Blakemore, W.F., et al. (2003) Neuropathological Assessment of Artemether-Treated Severe Malaria. The Lancet, 362, 295-296. http://dx.doi.org/10.1016/S0140-6736(03)13974-8

[55] Kissinger, E., Hien, T.T., Hung, N.T., Nam, N.D., Tuyen, N.L. and Dinh, B.V. (2000) Clinical and Neurophysiological Study of the Effects of Multiple Doses of Artemisinin on Brain-Stem Function in Vietnamese Patients. American Journal of Tropical Medicine and Hygiene, 63, 48-55.

[56] Van Vugt, M., Angus, B.J., Price, R.N., Mann, C., Simpson, J.A. and Poletto, C. (2000) A Case-Control Auditory Evaluation of Patients Treated with Artemisinin Derivatives for Multidrug-Resistant Plasmodium Falciparum Malaria. American Journal of Tropical Medicine and Hygiene, 62, 65-69.

[57] Maude, R.J., Woodrow, C.J. and White, L.J. (2010) Artemisinin Antimalarials: Preserving the “Magic Bullet”. Drug Development Research, 71, 12-19.

[58] Brewer, T.G., Grate, S.J., Peggins, J.O., Weina, P.J., Petras, J.M. and Levine, B.S. (1994) Fatal Neurotoxicity of Arteether and Artemether. American Journal of Tropical Medicine and Hygiene, 51, 251-259.

[59] Izunya, A.M., Nwaopara, A.O., Aigbiremolen, A., Odike, M.A.C., Oaikhena, G.A. and Bankole, J.K. (2010) Histological Effects of Oral Administration of Artesunate on the Liver in Wistar Rats. Research Journal of Applied Sciences, Engineering and Technology, 2, 314-318.

[60] Huda, S.N., Shahab, T., Al, S.M., Afzal, K. and Khan, H.M. (2003) A Comparative Clinical Trial of Artemether and Quinine in Children with Severe Malaria. Indian Paediatrics, 40, 939.

\section{Abbreviations}

TG: Triglyceride;

T.Chol: Total Cholesterol;

HDL-C: High Density Lipoprotein Cholesterol;

LDL-C: Low Density Lipoprotein Cholesterol;

VLDL-C: Very Low Density Lipoprotein Cholesterol;

MBCD: Methyl $\beta$-Cyclodextrin;

MP: Malaria Parasite;

WBC: White Blood Cells;

I.M: Intramuscular;

P.O: Per Oral;

ACT: Artemisinin Combination Therapy. 